Editorial

\title{
Optimalisasi 1000 Hari Pertama Kehidupan: Nutrisi, Kasih Sayang, Stimulasi, dan Imunisasi Merupakan Langkah Awal Mewujudkan Generasi Penerus yang Unggul
}

\author{
Hartono Gunardi \\ Departemen IImu Kesehatan Anak Fakutas Kedokteran Universitas Indonesia \\ Korespondensi: h_gunardi@yahoo.com \\ Disetujui: 2 Januari 2021 \\ DOI: $10.23886 /$ ejki.9.2.
}

\section{Pendahuluan}

Pembangunan Berkelanjutan (Sustainable Development Goals, SDGs) yang ditargetkan pada tahun 2030 bertujuan untuk menjamin kehidupan yang sehat dan mempromosikan kesejahteraan bagi semua usia. $^{1}$ Selaras dengan SDGs, pemerintah mencanangkan Visi Indonesia 2045 untuk menjadi negara berdaulat, maju, adil dan makmur.

Indonesia, sejak tahun 2020 , sedang mengalami bonus demografi, ketika proporsi penduduk usia produktif (15-64 tahun) lebih banyak dibandingkan proporsi penduduk usia non-produktif, sehingga pembangunan manusia menjadi pilar pertama dari 4 pilar Visi Indonesia 2045. Anak sebagai bagian dari generasi pemuda merupakan pusat bonus demografi yang menjadi kunci penting dalam mencapai Visi Indonesia $2045 .{ }^{2}$

Pandemi COVID-19 yang terjadi sejak awal tahun 2020 telah mengubah kehidupan. Pandemi COVID-19 berdampak besar pada pelayanan kesehatan ibu dan anak antara lain penimbangan balita di posyandu, suplementasi vitamin A, dan imunisasi. Menurunnya kunjungan layanan kesehatan ibu dan anak menghambat pencapaian target penurunan stunting. Pemerintah berhasil menurunkan stunting dari 37,2\% pada tahun 2013 menjadi $27,67 \%$ pada 2019 , namun perlu kerja keras bersama untuk mencapai target $14 \%$ pada tahun $2024{ }^{3}$

Sekitar 4,7 juta bayi yang lahir di Indonesia pada tahun $2019^{3}, 29,5 \%$ diantaranya adalah bayi prematur dan $6,2 \%$ adalah bayi berat lahir rendah. ${ }^{4}$ Kelompok tersebut merupakan bayi risiko tinggi untuk terjadinya gangguan pertumbuhan terutama stunting dan gangguan perkembangan seperti terlambat bicara, cerebral palsy (CP), disabilitas intelektual bahkan kematian. Makin kecil masa gestasi, makin tinggi risiko kematian dan gangguan tumbuh kembang seperti CP. ${ }^{5}$

\section{Hari Pertama Kehidupan}

Masa 1000 hari pertama kehidupan (HPK) dimulai saat pembuahan sampai usia 2 tahun; merupakan periode emas yang sangat menentukan masa depan anak. Periode tersebut merupakan masa kritis karena otak sedang berkembang pesat sehingga sangat rentan terhadap pengaruh lingkungan yang memengaruhi struktur otak dan kemampuan kognitif.

Pada masa 1000 HPK kebutuhan anak terutama nutrisi, kasih sayang dan stimulasi perlu dipenuhi. Bila menderita malnutrisi maka anak akan kurus (wasting) dan pendek (stunting) yang mengakibatkan perkembangan terhambat, kemampuan kognitif rendah, prestasi sekolah rendah, durasi pendidikan lebih singkat, dan saat dewasa mempunyai produktivitas serta kualitas hidup rendah yang berkontribusi terhadap kemiskinan dan inequalitas pada siklus kehidupan dan mungkin pula pada generasi selanjutnya. ${ }^{6}$ Pada periode berikutnya, anak stunting cenderung kelebihan gizi karena metabolisme lemak lebih lambat. Anak dapat mengalami obesitas dan menderita sindrom metabolik pada saat dewasa sehingga berisiko menderita diabetes melitus dan penyakit kardiovaskuler. ${ }^{7}$

\section{Nutrisi \\ Nutrisi lbu Hamil}

Nutrisi ibu hamil sangat penting karena memengaruhi perkembangan janin, organogenesis dan pembentukan saraf. ${ }^{8}$ Kekurangan nutrien makro yaitu protein, lemak termasuk long- 
chain polyunsaturated fatty acid (LC-PUFA) dan karbohidrat berhubungan dengan tingkat IQ rendah, keberhasilan sekolah rendah, serta disregulasi perilaku. ${ }^{9}$ Selain itu diperlukan nutrien mikro seperti zat besi, zink, tembaga, yodium, selenium dan berbagai vitamin seperti vitamin $A, B$, $\mathrm{K}$, asam folat dan choline. ${ }^{10}$

Defisiensi dan gangguan transpor zat besi dari ibu ke janin meningkatkan risiko defisiensi zat besi pada bayi baru lahir dan berhubungan dengan berkurangnya fungsi kognitif jangka panjang. ${ }^{10}$ Yodium berperan pada sintesis hormon tiroid yang penting untuk perkembangan otak. Defisiensi yodium menyebabkan kretinisme pada anak dengan keterbelakangan mental berat dan permanen. Kekurangan yodium derajat ringan dan sedang dalam jangka panjang menyebabkan penurunan IQ. ${ }^{11}$ Zink memengaruhi pembentukan lempeng pertumbuhan anak karena berperan pada lebih dari 100 enzim dan ribuan faktor transkripsi. ${ }^{12}$ Masukan zink yang rendah berhubungan dengan prevalensi stunting pada anak balita. ${ }^{13}$

\section{Nutrisi Bayi Usia 6 Bulan Pertama}

ASI merupakan sumber nutrisi terbaik untuk bayi dan paling efektif untuk menjamin kesehatan dan kesintasan anak sehingga dianjurkan pemberian ASI eksklusif selama 6 bulan. Untuk keberhasilan menyusui perlu dilakukan inisiasi menyusui dini 1 jam setelah bayi lahir. Selain mencukupi kebutuhan nutrisi, pemberian ASI menyalurkan kasih sayang ibu dan sarana stimulasi refleks isap serta stimulasi seluruh organ sensoris bayi yang berguna untuk perkembangan bayi selanjutnya. Bayi yang mendapat ASI memperlihatkan tingkat kecerdasan (IQ lebih tinggi 3,5 poin) lebih baik dibandingkan bayi yang mendapat susu formula. Pada penelitian longitudinal selama 30 tahun, bayi yang mendapat ASI selama 12 bulan mengalami peningkatan IQ 3,7 poin pada usia 30 tahun, durasi pendidikan lebih lama 1 tahun dan penghasilan per bulan lebih tinggi (lebih tinggi 167 USD pada tahun 2012) dibandingkan bayi yang mendapat ASI kurang dari 1 bulan. ${ }^{14}$

\section{Nutrisi Bayi Setelah Usia 6 Bulan}

Makanan pendamping ASI (MP-ASI) yang tepat waktu, cukup kalori, protein, vitamin, mineral, higienis dan responsif diberikan setelah bayi berusia 6 bulan dan ASI dapat diteruskan sampai usia 2 tahun. Karena tumbuh kembang berlangsung pesat, diperlukan nutrien seperti protein, kalsium dan vitamin $D$ untuk pembentukan massa tulang serta mencegah rikets. LC-PUFA, terutama DHA dan karotenoid diperlukan untuk perkembangan otak dan mata. ${ }^{8}$ MP-ASI yang kurang dalam kuantitas dan kualitas akan menimbulkan growth faltering yang bila berlangsung lama dapat terjadi malnutrisi dan stunting pada anak 6-23 bulan. ${ }^{15}$

Pandemi COVID-19 berpotensi memengaruhi ketersediaan pangan pada keluarga yang kurang beruntung sehingga anak berisiko kekurangan protein hewani yang meningkatkan risiko stunting. ${ }^{16}$ Oleh karena itu, pemantauan tumbuh kembang perlu dilakukan baik secara mandiri oleh orangtua maupun oleh posyandu atau fasyankes dengan memenuhi protokol kesehatan.

\section{Kasih Sayang}

Kebutuhan dasar anak selain nutrisi adalah kasih sayang. Pola pengasuhan yang responsif dan penuh kasih sayang dibutuhkan untuk menimbulkan rasa aman dan kepercayaan pada anak. Kurangnya pemenuhan kasih sayang akan menimbulkan ketidakpercayaan anak terhadap lingkungan dan deprivasi emosi yang selanjutnya dapat menyebabkan gagal tumbuh.

\section{Stimulasi}

Saat lahir, bayi mempunyai sekitar 100 milyar sel neuron yang hubungannya dengan neuron lain masih lemah atau belum terhubung sama sekali. Pengalaman baru yang diperoleh dari panca indera akan membentuk hubungan antar neuron atau sinaps baru. Makin sering dan beragam pengalaman stimulasi yang diperoleh, hubungan sinaps semakin kuat dan kompleks. Sinaps yang sering digunakan akan menetap sedangkan yang jarang digunakan akan menghilang. Berbagai stimulasi lingkungan, baik positif maupun negatif, dapat memengaruhi otak untuk mengatur ulang organisasi jaringan saraf yang dikenal sebagai plastisitas otak. Dengan demikian stimulasi berperan langsung terhadap fungsi maupun struktur otak.

Jika anak tidak mendapat stimulasi yang memadai pada masa 1000 HPK maka timbul dampak negatif yang menetap. Sebagai contoh adalah strabismus. Pada mata normal, rangsang penglihatan dari kedua mata akan bersatu di korteks visual lobus oksipital. Pada strabismus, tidak ada hubungan salah satu mata ke korteks visual sehingga kemampuan melihat secara tiga dimensi menghilang. ${ }^{17}$ Selain pembentukan sinaps, terjadi proses mielinisasi yang berfungsi pada pengiriman impuls secara cepat yang berhubungan dengan kemampuan kognitif anak seperti memori kerja spasial, inhibisi, membaca serta aritmatik di kemudian hari. ${ }^{18}$ 
Lingkungan yang baik adalah lingkungan yang sensitif dan responsif terhadap pemenuhan kebutuhan anak. Kurangnya pemenuhan kebutuhan anak dalam kasih sayang dan stimulasi menimbulkan gangguan perkembangan anak. Hal tersebut terlihat pada anak yang diadopsi dari panti asuhan internasional seperti di Rusia, Romania dan negara lainnya setelah usia 24 bulan menunjukkan gangguan perkembangan lebih berat dan lebih menetap dibandingkan anak yang diadopsi lebih muda. ${ }^{19}$ Selain itu, pengalaman negatif seperti kurangnya interaksi dengan orangtua, pajanan gawai dalam bentuk screen time yang berlebihan, kekerasan atau penelantaran anak pada masa 1000 HPK menimbulkan dampak negatif menetap.

\section{Stimulasi dengan Gawai}

Sesuai dengan meningkatnya penggunaan media elektronik di Indonesia, pajanan screen time pada anak juga meningkat, apalagi pada masa pandemi COVID-19. Screen time dapat berasal dari TV, gawai, komputer atau telepon genggam. Terdapat hubungan pajanan screen time dengan keterlambatan bicara reseptif dan ekspresif. ${ }^{20}$ Keterlambatan bicara merupakan masalah perkembangan anak yang paling banyak dijumpai di RSCM (14,3\% pada tahun 2019). Penelitian metaanalisis 38 studi (18.313 partisipan) untuk menilai kuantitas screen time, didapatkan efek gabungan yang negatif dan bermakna [ $\mathrm{r}=-0,14$ (IK95\%: $-0,18 \mathrm{~s} / \mathrm{d}-0,10)]$, yang berarti semakin besar kuantitas penggunaan layar berhubungan dengan rendahnya kemampuan bahasa anak. ${ }^{21}$ Pajanan screen time pada usia dini berhubungan dengan risiko gangguan interaksi dan perilaku seperti autisme dan attention deficit hyperactivity disorder (ADHD). Penelitian pada 2.152 anak di Amerika Serikat menunjukkan anak yang terpajan screen time pada usia 12 bulan berhubungan dengan peningkatan gejala mirip autis ( $A S D$-like symptom) dibandingkan anak yang tidak terpajan layar, yang dinilai dengan total skor M-CHAT R (perubahan 4,2\%; IK95\%: 0,1\%-8,3\%). ${ }^{22}$ Sebaliknya, anak yang bermain dengan orangtua setiap hari pada usia 12 bulan berhubungan dengan lebih sedikit gejala mirip autis dibandingkan dengan yang bermain kurang dari setiap hari (perubahan $-8,9 \%$; IK95\%: $-16,5 \%$ s/d $-0,9 \%) .22$

\section{Penggunaan Media Digital pada Anak}

WHO tidak merekomendasikan penggunaan media digital (screen time) untuk anak $<1$ tahun. American Academy of Pediatrics juga tidak menganjurkan penggunakan screen time pada anak < 18 bulan kecuali untuk video chatting (dengan orangtua yang berada di luar kota). Pada anak usia 18-24 bulan, screen time hanya digunakan untuk program belajar yang baik pada anak dan perlu didampingi orangtua. Pada anak $>2$ tahun, screen time direkomendasikan 1 jam per hari untuk program belajar berkualitas yang perlu pendampingan interaktif oleh orangtua. ${ }^{23}$

\section{Stimulasi Ideal pada 1000 HPK}

Stimulasiadalah proses pemberian rangsangan pada satu atau semua organ sensoris (penglihatan, pendengaran, perabaan, vestibuler, penciuman, pengecapan) pada anak. Salah satu cara stimulasi multisensori alami terbaik yang dapat diberikan ibu adalah menyusui karena dapat merangsang refleks isap, pengecapan, pendengaran (melalui denyut jantung ibu, senandung atau percakapan ibu dengan bayi), penglihatan (tatapan mata ibu interaktif kepada mata bayi saat terjaga), merangsang penciuman (dengan aroma ibu yang spesifik) dan merangsang perabaan kulit bayi (dengan belaian ibu).

Metode stimulasi multisensori lain adalah stimulasi auditory-tactile-visual-vestibular (ATVV) dengan pijat bayi (stimulasi perabaan) bersama suara ibu (stimulasi pendengaran) diikuti dengan menimang bayi (stimulasi vestibuler) yang pada bayi prematur dapat meningkatkan asupan ASI dan memperpendek masa perawatan di rumah sakit. Studi meta-analisis yang meliputi 13 penelitian, memperlihatkan stimulasi multisensoris yang diberikan pada bayi prematur di NICU menyatakan indeks perkembangan mental dan psikomotor bayi lebih baik secara bermakna pada usia 12 bulan dibandingkan kontrol. ${ }^{24}$ Untuk anak lebih besar, orangtua dapat melakukan stimulasi secara interaktif pada ranah perkembangan bicara dan bahasa, gerak kasar, gerak halus dan personal sosial menggunakan petunjuk stimulasi sesuai buku Kesehatan Ibu dan Anak yang telah direvisi tahun 2020 atau program stimulasi anak pada aplikasi Primaku yang dikembangkan IDAI.

\section{Imunisasi}

Anak, terutama dalam periode $1000 \mathrm{HPK}$, perlu dilindungi dari penyakit yang dapat dicegah dengan imunisasi (PD3I). Imunisasi adalah cara paling efektif untuk mencegah penyakit infeksi dan diestimasi dapat menyelamatkan 2-3 juta anak setiap tahun di seluruh dunia. ${ }^{25}$ Infeksi persisten atau rekuren pada 1000 HPK dapat menimbulkan malnutrisi 
dan stunting. Vaksin campak mencegah penyakit campak yang dapat merusak sistem kekebalan sehingga meningkatkan kerentanan terhadap infeksi 2-3 tahun sesudahnya. Vaksin campak mempunyai efek proteksi spesifik dan non-spesifik terhadap penyakit lain melalui induksi memori imun bawaan terlatih yang dimediasi oleh pemrograman ulang epigenetik dan transkripsi sel imun. ${ }^{26}$

Imunisasi juga dapat meningkatkan pertumbuhan dan perkembangan anak. Penelitian longitudinal pada 2000 anak di Etiopia, India dan Vietnam memperlihatkan hubungan imunisasi campak pada usia 6-18 bulan dengan peningkatan skor Z antropometri 0,1-0,2. Persentase skor uji kognitif standar lebih tinggi 1,7-4,5 poin dan tingkat sekolah lebih tinggi 0,2-0,3 tahun pada usia 7-8 dan 11-12 tahun. ${ }^{27}$

Pada awal pandemi COVID-19 cakupan imunisasi secara nasional menurun karena 84\% fasilitas pelayanan kesehatan (fasyankes) terganggu dan $76 \%$ orangtua kuatir terjangkit COVID-19 saat kunjungan imunisasi. Analisis manfaat risiko imunisasi rutin pada masa pandemi melaporkan satu kematian anak karena COVID-19 akibat kunjungan imunisasi rutin dapat menyelamatkan 82 kematian karena PD3I. ${ }^{28}$ Dengan demikian imunisasi anak perlu dilanjutkan dengan mematuhi protokol kesehatan yang dianjurkan untuk fasyankes, orangtua dan anak.

Selain imunisasi rutin yang direkomendasikan kemenkes, anak perlu dilengkapi dengan imunisasi pilihan terutama vaksin pneumokokus dan rotavirus yang merupakan penyebab morbiditas dan mortalitas tersering pertama dan kedua di dunia. ${ }^{29}$ Imunisasi pilihan belum dapat dilaporkan melalui sistem pelaporan imunisasi kemenkes, namun dapat dilaporkan melalui IDAI Pediatric Online Immunization Reporting System (I-POINTS) yang dikembangkan oleh IDAI bersama American Academy of Pediatrics. ${ }^{30}$

\section{Pemantauan Tumbuh Kembang}

Bayi cukup bulan berisiko mengalami gangguan perkembangan sebesar $1,7 \%$ sedangkan bayi kurang bulan, bayi berat lahir rendah mempunyai risiko lebih besar yaitu $17 \% .{ }^{31}$ Penelitian pada 238 bayi kurang bulan dengan berat lahir 1000-1499 g, diperoleh kejadian gagal tumbuh $84,5 \%$ pada saat bayi pulang dari rumah sakit. ${ }^{31}$ Bayi kurang bulan dan bayi berat lahir rendah merupakan kategori bayi risiko tinggi untuk terjadinya gangguan tumbuh kembang. Dengan demikian, tumbuh kembang semua bayi terutama bayi risiko tinggi perlu dipantau secara teratur dan berkala.

Pemantauan perkembangan di tingkat keluarga dapat dilakukan dengan buku Kesehatan Ibu dan Anak (KIA) atau dengan kuesioner praskrining perkembangan pada aplikasi Primaku, salah satu aplikasi IDAI untuk orangtua. Pada tingkat rumah sakit, skrining perkembangan anak dilakukan menggunakan Parents' Evaluation of Developmental Status, Denver II atau Bayley Infant Neurodevelopmental Screener (BINS) atau dengan Capute Scale. Selanjutnya dapat dilakukan penilaian menggunakan Bayley Scales of Infant Development III sebagai baku emas perkembangan anak.

\section{Kiprah Divisi TKPS}

Alat skrining perkembangan anak yang lebih baru, akurat dan banyak digunakan di negara maju dan sedang berkembang adalah Ages \& Stages Questionnaires III (ASQ III). Saat ini Divisi Tumbuh Kembang Pediatri Sosial (TKPS) berhasil melakukan translasi dan adaptasi ke Bahasa Indonesia serta melakukan uji validasi dan reliabilitas ASQ III untuk seluruh kelompok usia dari 4-44 bulan. ASQ III versi Bahasa Indonesia telah dilakukan uji validasi eksternal ke Bayley Scales of Infant Development (BSID) III untuk kelompok usia 24, 30 dan 36 bulan dengan sensitifitas gabungan 78\% (IK95\%: 65-90\%) dan spesifisitas gabungan 71\% (IK95\%: 62-80\%). ${ }^{32}$ Dengan demikian, skrining tumbuh kembang anak di RSCM diharapkan sesuai dengan standar internasional setelah didapatkan lisensi izin penggunaan dari institusi terkait.

Seiring dengan meningkatnya penggunaan gawai pada anak, terjadi peningkatan kejadian keterlambatan bicara dan bahasa pada anak. Terdapat hubungan peningkatan risiko keterlambatan bicara dengan peningkatan penggunaan screen time pada anak. ${ }^{33}$ Oleh karena itu, keterlambatan bicara perlu dideteksi secara dini. Untuk mendeteksi gangguan komunikasi dan interaksi pada usia dini, yaitu pada usia 6-24 bulan, dapat digunakan Communication and Symbolic Behavior Scales Developmental Profile (CSBS DP) Infant/Toddler Checklist. CSBS DP telah ditranslasi oleh peneliti divisi TKPS Departemen IImu Kesehatan Anak (IKA) FKUI-RSCM. Uji kesahihan dan keandalan memberikan hasil baik dengan Cronbach's alpha 0,876-0,896. ${ }^{34}$

Selain melakukan pendidikan dan pelayanan imunisasi, Divisi TKPS Departemen IKAFKUI-RSCM berkiprah dalam penelitian uji klinis vaksin seperti vaksin DTP-HB-Hib, dibawah bimbingan Prof. Dr. dr. Sri Rezeki S Hadinegoro, Sp.A(K) berkolaborasi 
dengan tim FK Universitas Padjadjaran-RS Hasan Sadikin yang dipimpin oleh Prof. Dr. dr. Kusnandi Rusmil, Sp.A(K) dengan mitra Bio Farma yang diwakili oleh Dr. dr. Novilia Sjafri Bachtiar, M.Kes. Vaksin DTP-HB-Hib memperlihatkan keamanan dan imunogensitas yang baik pada anak usia 2,3,4 bulan $^{35}$ dan menunjukan persistensi serta respons kenaikan antibodi yang baik setelah pemberian dosis booster pada anak usia 18-24 bulan. ${ }^{36}$ Saat ini vaksin DTP-HB-Hib dipakai pada program nasional sebagai imunisasi rutin pada anak usia 2,3,4 bulan dan 18 bulan. ${ }^{37}$ Uji klinis vaksin lainnya adalah imunogenisitas dan keamanan vaksin influenzae trivalen, ${ }^{38}$ keamanan dan imunogenisitas polisakarida Salmonella typhi konjugasi dengan toksoid difteri, fase 1 dan fase 2 yang dapat diberikan pada anak mulai usia 9 bulan. ${ }^{39,40}$

\section{Kesimpulan}

Untuk tumbuh kembang optimal, kebutuhan dasar anak perlu dipenuhi terutama nutrisi yang mengandung nutrien makro, mikro, kasih sayang yang memberikan rasa aman dan percaya diri serta stimulasi memadai untuk perkembangan otak optimal pada masa $1000 \mathrm{HPK}$. Selain itu anak perlu dilindungi dari penyakit infeksi yang berbahaya dengan imunisasi dan pola pengasuhan yang penuh kasih sayang. Semua itu merupakan langkah awal yang diperlukan dalam mewujudkan generasi penerus Indonesia unggul dan tangguh pada tahun 2045.

Naskah ini Merupakan Ringkasan Pidato Pengukuhan Guru Besar Prof. Dr. dr. Hartono Gunardi, Sp.A(K) di Jakarta, aula FKUI, 13 Februari 2021.

\section{Daftar Pustaka}

1. WHO. Sustainable development goals (SDGs). Geneve: WHO; 2020. Diakses 3 Januari 2021. Diunduh dari https://www.who.int/health-topics/ sustainable-development-goals\#tab= tab _1.

2. Kementerian Pendidikan dan Kebudayaan RI. Peta jalan generasi emas Indonesia 2045. Jakarta: Kementerian Pendidikan dan Kebudayaan RI; 2017.

3. Kementerian Kesehatan RI. Profil kesehatan Indonesia tahun 2019. Diakses 3 Januari 2021. Diunduh dari https://pusdatin.kemkes.go.id/ resources/download/pusdatin/profil-kesehatanindonesia/Profil-Kesehatan-indonesia-2019.pdf

4. Kementerian Kesehatan RI. Laporan nasional riset kesehatan dasar (riskesdas) 2018. Diakses 3 Januari 2021. Diunduh dari https://archive.org/details/ Laporan Riskesdas2018NasionalPromkes.net

5. Woythaler M. Neurodevelopmental outcomes of the late preterm infant. Semin Fetal Neonatal Med. 2019;24:54-9.

6. Martorell R, Zongrone A. Intergenerational influences on child growth and undernutrition. Paediatr Perinat Epidemiol. 2012;26 Suppl 1:302-14.

7. Hoffman DJ. Growth retardation and metabolic programming: implications and consequences for adult health and disease risk. J Pediatr (Rio J). 2014;90:325-8.

8. Beluska-Turkan K, Korczak R, Hartell B, Moskal K, Maukonen J, Alexander DE, et al. Nutritional gaps and supplementation in the first 1000 days. Nutrients. 2019;11:2891.

9. Grantham-McGregor S. A review of studies of the effect of severe malnutrition on mental development. J Nutr. 1995;125(8 Suppl):2233S-8S.

10. Georgieff MK, Brunette KE, Tran PV. Early life nutrition and neural plasticity. Dev Psychopathol. 2015;27:411-23.

11. Prado EL, Dewey KG. Nutrition and brain development in early life. Nutr Rev. 2014;72:267-84.

12. Andreini C, Banci L, Bertini I, Rosato A. Counting the zinc-proteins encoded in the human genome. J Proteome Res. 2006;5:196-201.

13. Millward DJ. Nutrition, infection and stunting: the roles of deficiencies of individual nutrients and foods, and of inflammation, as determinants of reduced linear growth of children. Nutr Res Rev. 2017;30:50-72.

14. Victora CG, Horta BL, Loret de Mola C, Quevedo L, Pinheiro RT, Gigante DP, et al. Association between breastfeeding and intelligence, educational attainment, and income at 30 years of age: a prospective birth cohort study from Brazil. Lancet Glob Health. 2015;3:e199-205.

15. Limardi S HD, Sidiartha IGL, Utami NMD. Investigating minimum acceptable diet and infant and child feeding index as indicators of stunting in children aged 6-23 months Paediatr Indones. 2020;60:259-68.

16. Sari M, de Pee S, Bloem MW, Sun K, Thorne-Lyman $A L$, Moench-Pfanner $R$, et al. Higher household expenditure on animal-source and nongrain foods lowers the risk of stunting among children 0-59 months old in Indonesia: implications of rising food prices. J Nutr. 2010;140:195S-200S.

17. Wang PP. Nature, nurture, and their interactions in child development and behavior. Dalam: Voigt RG, Myers SM, penyunting. Developmental and behavioral pediatrics. Itasca: American Academy of Pediatrics; 2011.p.5-20.

18. Chevalier N, Kurth S, Doucette MR, Wiseheart M, Deoni SC, Dean DC, et al. Myelination is associated with processing speed in early childhood: preliminary insights. PLoS One. 2015;10:e0139897.

19. Juffer $\mathrm{F}$, van ljzendoorn $\mathrm{MH}$. Behavior problems and mental health referrals of international adoptees: a meta-analysis. JAMA. 2005;293:2501-15.

20. van den Heuvel M, Ma J, Borkhoff CM, Koroshegyi 
C, Dai DWH, Parkin PC, et al. Mobile media device use is associated with expressive language delay in 18-month-old children. J Dev Behav Pediatr. 2019;40:99-104.

21. Madigan S, McArthur BA, Anhorn C, Eirich R, Christakis DA. Associations between screen use and child language skills: a systematic review and meta-analysis. JAMA Pediatr. 2020;174:665-75.

22. Heffler KF, Sienko DM, Subedi K, McCann KA, Bennett DS. Association of early-life social and digital media experiences with development of autism spectrum disorder-like symptoms. JAMA Pediatr. 2020;174:690-6.

23. AAP. Where we stand: screen time. 2016. Diakses 4 Januari 2021. Diunduh dari https://www. healthychildren.org/English/family-life/Media/Pages/ Where-We-Stand-TV-Viewing-Time.aspx.

24. Soleimani F, Azari N, Ghiasvand H, Shahrokhi A, Rahmani N, Fatollahierad S. Do NICU developmental care improve cognitive and motor outcomes for preterm infants? A systematic review and metaanalysis. BMC Pediatr. 2020;20:67.

25. WHO. Vaccines and immunization. 2021. Diakses 9 Januari 2021. Diunduh dari https:// www.who.int/ health-topics/vaccines-andimmunization\#tab=tab 1.

26. Mina MJ. Measles, immune suppression and vaccination: direct and indirect nonspecific vaccine benefits. J Infect. 2017;74 Suppl 1:S10-S17.

27. Nandi A, Shet A. Why vaccines matter: understanding the broader health, economic, and child development benefits of routine vaccination. Hum Vaccin Immunother. 2020;16:1900-4.

28. Abbas K, Procter SR, van Zandvoort K, Clark A, Funk $S$, Mengistu T, et al. Routine childhood immunisation during the COVID-19 pandemic in Africa: a benefitrisk analysis of health benefits versus excess risk of SARS-CoV-2 infection. Lancet Glob Health. 2020;8:e1264-e72.

29. Liu L, Hill K, Oza S, Hogan D, Chu Y, Cousens S, et al. Levels and causes of mortality under five years. Dalam: Black RE, Laxminarayan R, Temmerman M et al, penyunting. Reproductive, maternal, newborn and child health. Washington: The World Bank; 2016.p.71-83.

30. Gunardi H. IDAI Pediatric online immunization reporting system. Dalam: Wahab AS, penyunting. Kumpulan Makalah Konika XVII implementing advances in pediatrics for better child health. Yogyakarta: BP IDAI; 2017.p.298-302.

31. Leksomono HE, Sutomo R. Predictors of early growth failure in preterm, very low birth weight infants during hospitalization. Paediatr Indones. 2019;59:44-50.

32. Yunilda E. Uji kesahihan eksterna ages and stages questionnaires-third edition (ASQ-3) Bahasa Indonesia terhadap Bayley Scales of Infant Development-III sebagai uji tapis perkembangan anak usia 24-30-36 bulan (tesis). Jakarta: Universitas Indonesia; 2020.

33. Madigan S, Browne D, Racine N, Mori C, Tough $\mathrm{S}$. Association between screen time and children's performance on a developmental screening test. JAMA Pediatr. 2019;173:244-50.

34. Supit DM. Uji kesahihan dan keandalan communication and symbolic behavior scales developmental profile (Csbs Dp) infant/toddler checklist Bahasa Indonesia sebagai alat uji penapisan gangguan komunikasi pada anak usia 6-24 bulan (tesis). Jakarta: Universitas Indonesia; 2019.

35. Rusmil K, Gunardi H, Fadlyana E, Soedjatmiko, Dhamayanti M, Sekartini R, etal. The immunogenicity, safety and consistency of an Indonesia combined DTP-HB-Hib vaccine in expanded program on immunization schedule. BMC Pediatr. 2015;15:219.

36. Gunardi H, Rusmil K, Fadlyana E, Soedjatmiko, Dhamayanti M, Sekartini R, et al. DTwP-HB-Hib: antibody persistence after a primary series, immune response and safety after a booster dose in children 18-24 months old. BMC Pediatr. 2018;18:177.

37. Soedjatmiko S, Medise BE, Gunardi H, Sekartini R, Satari HI, Hadinegoro SR, et al. Immunogenicity and safety of a trivalent influenza HA vaccine in Indonesian infants and children. Vaccine. 2018;36:2126-32.

38. Medise BE, Soedjatmiko S, Rengganis I, Gunardi H, Sekartini R, Koesno S, et al. Six-month follow up of a randomized clinical trial-phase I study in Indonesian adults and children: safety and immunogenicity of S. typhi polysaccharide-diphtheria toxoid (Vi-DT) conjugate vaccine. PLoS One. 2019;14:e0211784.

39. Medise BE, Soedjatmiko S, Gunardi H, Sekartini R, Satari HI, Hadinegoro SR, et al. A novel Vi-diphtheria toxoid typhoid conjugate vaccine is safe and can induce immunogenicity in healthy Indonesian children 2-11 years: a phase II preliminary report. BMC Pediatr. 2020;20:480.

40. Medise BE, Soedjatmiko S, Gunardi H, Sekartini R, Satari HI, Hadinegoro SR, et al. One-month follow up of a randomized clinical trial-phase II study in 6 to $<24$ months old Indonesian subjects: safety and immunogenicity of Vi-DT typhoid conjugate vaccine. Int J Infect Dis. 2020;93:102-7. 